\title{
Hepatopulmonary Syndrome: A Brief Review
}

\author{
ZULKIFLI AMIN ${ }^{1}$, HILMAN ZULKIFLI AMIN ${ }^{2}$, NADIM MARCHIAN TEDYANTO ${ }^{3}$ \\ ${ }^{1}$ Division of Respirology and Critical Care, Department of Internal Medicine, Faculty of Medicine, \\ University of Indonesia, Jakarta, Indonesia \\ ${ }^{2}$ Department of Internal Medicine, Faculty of Medicine, University of Indonesia, Jakarta, Indonesia \\ ${ }^{3}$ Faculty of Medicine, University of Indonesia, Jakarta, Indonesia
}

\begin{abstract}
Hepatopulmonary syndrome (HPS) is a pulmonary complication of liver disease characterized by arterial hypoxemia. Mechanisms related to this event are diffusion-perfusion flaw, ventilationperfusion (V/Q) mismatch, and direct arteriovenous shunts. Diagnosis of HPS is based on the presence of liver disease or portal hypertension, increased alveolar-arterial (A-a) $\mathrm{PO}_{2}$, and intrapulmonary vascular dilatations (IPVD). Lung transplantation (LT) remains the most effective therapy for HPS. In spite of its poor prognosis, we could improve the quality of life and survival rate of patients.
\end{abstract}

Key words: Hepatopulmonary syndrome, liver cirrhosis, liver disease, lung disease, portal hypertension.

\section{INTRODUCTION}

Hepatopulmonary syndrome (HPS) is a pulmonary complication of liver disease characterized by arterial hypoxemia. This condition often manifests in adult patients with terminal liver disease, having a prevalence of $4 \%$ to $32 \%$ [1]. It is distinguished by three specific clinical entities consisting of liver disease and/or portal hypertension, disturbance of alveolar-arterial oxygen gradient, and intrapulmonary vascular dilatations (IPVD) [2].

The relationship between pulmonary disorder and liver disease has been recognized for more than 100 years. Despite years of research, diagnosing HPS is still difficult due to the existence of other comorbidities and unclear clinical presentation. Moreover, the only proven therapy for HPS is liver transplantation (LT) [3, 4]. Thus, early diagnosis of HPS is needed to put the patients in priority list for LT. For these reasons, a physician looking to diagnose and manage patients with HPS will need extensive knowledge and broad clinical experience. This review will briefly explain updates from the definition to the management of HPS.

\section{DEFINITION AND PREVALENCE}

Kennedy and Knudson were the first to describe cyanosis which emerged four years following porto-caval shunt surgery in a cirrhosis patient, a condition which would later be called HPS. It is defined by the existence of liver disease, disturbance of arterial oxygenation marked by elevated room air alveolar-arterial oxygen gradient $\left[\mathrm{P}(\mathrm{A}-\mathrm{a}) \mathrm{O}_{2}\right] \geq 15 \mathrm{mmHg}$ or $\geq 20 \mathrm{mmHg}$ if the patient's age $\geq 65$ years or arterial partial pressure oxygen $\left(\mathrm{PaO}_{2}\right)<80 \mathrm{mmHg}$ during room air breathing without other identifiable cause, and IPVD diagnosed by contrast transthoracic echocardiography or other accepted modality $[1,2]$. However, it is now known that HPS could manifest in patients with portal hypertension despite having no liver cirrhosis. Moreover, many studies have failed to establish a clear link between the severity of liver disorder and the presence of HPS. Consequently, clinical symptoms such as dyspnea, cyanosis, digital clubbing, orthodeoxia, and platypnea will have more diagnostic value in establishing a more reliable definition $[5,6]$.

The estimated prevalence of HPS is $4 \%$ to $32 \%$ among chronic liver disease patients. The cause of this wide range of prevalence is the variation of diagnostic criteria and study populations used in related studies. Abrams et al. detected IPVDs in $38 \%$ of cirrhosis patients using biopsy in conjunction with microbubble transthoracic echocardiography (MTTE), but only $17.5 \%$ of cirrhosis patients had an arterial oxygenation defect as detected by blood gas analysis. However, other studies found a wide range of IPVDs prevalence (13-80\%) in LT candidates [7]. These studies had also found that mild IPVDs without any ab- 
normality in arterial oxygenation were more frequent than previously expected in cirrhosis patient. The European Respiratory Task Force had proposed the staging of HPS according to the level of $\mathrm{PO}_{2}$. HPS is considered to be mild when $\mathrm{PO}_{2} \geq 80 \mathrm{mmHg}$, moderate when $\mathrm{PO}_{2}$ 60-79 $\mathrm{mmHg}$, severe when $\mathrm{PO}_{2} \geq 80 \mathrm{mmHg}$, and very severe when $\mathrm{PO}_{2}<$ $50 \mathrm{mmHg}[1,2]$.

\section{ETIOLOGY AND PATHOPHYSIOLOGY}

The definitive cause of HPS has not been clearly determined. Some clinical studies have suggested that reduced pulmonary vascular tone and advanced liver disorder are the main causes. Other studies have also found that exhaled NO level is elevated in cirrhotic patients with HPS compared to control, providing a clue of the role elevated pulmonary nitric oxide (NO) production has in causing HPS. Another contributing factor in elevated NO levels is the increased expression of inducible NO synthase (iNOS) due to increase in phagocytosis caused by bacterial endotoxin. This event could occur in portal hypertension, which will eventually result in intestines perfusion disturbance and increased rate of gram-negative bacteria and enteral endotoxin translocation. Moreover, it also induced the release of vasoactive mediators including NO $[1,6,8,9]$.

Plasma endothelin-1 (ET-1) could give rise to NO-associated vasodilatation through activation of endothelin $\mathrm{B}$ receptors $\left(\mathrm{ET}_{\mathrm{B}} \mathrm{R}\right)$ on endothelial cells. ET-1 levels were found to be elevated in cirrhosis and IPVD cases [9]. Macrophages could also induce vasodilatation due to heme oxygenase (HO-1) production that resulted in increased production of carbon monoxide (CO) [11]. Furthermore, gene polymorphisms also played a role in angiogenesis that had been linked with advanced HPS [12].

The aforementioned conditions lead to diffusion-perfusion flaw, ventilation-perfusion (V/Q) mismatch, and direct arteriovenous shunt. Diffusionperfusion flaw is caused by an increase of alveolar capillary diameter that expanded the binding space between oxygen molecules with hemoglobin. The combination of the aforementioned conditions with increased cardiac output and reduction of transit time that was usually shown in cirrhosis caused the red blood cells to leave the pulmonary capillaries before oxygen equilibrium was reached. V/Q mismatch is also caused by vascular dilatations. It could also be aggravated by hypoxic pulmonary vasoconstriction. Lastly, direct arteriovenous shunt could lead to hypoxemia due to mixture of arterial and venous blood $[1,9]$.

Studies using HPS animal model lung functions have identified a number of pathological changes consisting of decreased tidal volume, minute ventilation, lung airway resistance, and mean inspiratory flow, accompanied by elevated chest wall pressure dissipation and viscoelastic pressure. The amount of collagen volume in the vasculature was elevated by $29 \%$ in HPS animal models. In addition, cirrhotic patients also showed an increased level of lipopolysaccharide (LPS). Cirrhotic animal models that had been given extra LPS revealed abnormalities of lung anatomy and functions, such as reduction of cell density, expanded alveoli wall, constricted alveoli space, and obliteration of type 1 cell membrane solidity, along with a series of inflammatory reactions and interstitial pulmonary edema. These impairments lead to extensive dilatation of alveolar capillaries and increased permeability of vasculature [13].

\section{CLINICAL CHARACTERISTIC AND DIAGNOSIS}

Progressive dyspnea especially on activity is the most frequent complaint in HPS patients. LT candidates with HPS who described dyspnea amount to $48 \%$ in contrast to $\mathrm{LT}$ candidates without HPS or other lung disorder that amount to $29 \%(\mathrm{P}=0.007)$. Other symptoms or clinical signs associated with HPS were orthopnea, platypnea, cyanosis, and digital clubbing. It was also found that cyanosis in liver disease patients with HPS amount to $10 \%$ compared to $1 \%$ in liver disease patients without HPS $(\mathrm{P}=0.007)$. Moreover, digital clubbing was also more prevalent in a similar population $\left(17 v_{s} 7 \%, \mathrm{P}=0.03\right)$ [1]. Even though the aforementioned symptoms and clinical signs were not specific for the diagnosis of HPS, their presence may lead to an increased V/Q mismatch as the consequence of predominant vasodilation, especially in the basal parts of the lung $[14,15]$. Direct arteriovenous shunt and V/Q mismatch thus contributed to the occurrence of orthodeoxia. Spider angiomata and neurological complications could also be seen in HPS patients [16].

Diagnosis of HPS is based on the presence of liver disease or portal hypertension, increased P(Aa) $\mathrm{O}_{2}$, and IPVD. Blood gas analysis showed an 
increase of age-regulated $\mathrm{A}-\mathrm{a} \mathrm{PO}_{2}$ with or without hypoxemia. In addition, chest radiograph and other pulmonary function tests have to be done in order to exclude other possible pulmonary cause $[1,2,6$, 17]. The screening modalities used to assess IPVD are MTTE and technetium-labeled macroaggregated albumin (MAA) scan. MTTE is considered as the gold standard for diagnosing IPVD because the test is relatively less invasive and more sensitive compared to MAA scan. Even though transoesophageal contrast echocardiography may have a higher sensitivity to identify HPS, it had a lot of setbacks, such as the need for sedation, the risk of esophageal variceal bleeding, and a higher cost [18]. In addition to differentiating between intracardiac and intrapulmonary shunting, MTTE also had another advantage to detect pulmonary hypertension. Other tests such as pulmonary angiography and chest computerized tomography could show benefit in particular conditions, such as when large arteriovenosus shunt was suspected [1,2]. While clinical symptoms may not be definitive, a good history taking and comprehensive physical examination should help in establishing diagnosis.

Some recent studies have shown the potential of a more simple, non-invasive screening modality to detect HPS, such as pulse oximetry. The pulse oximetry method was associated with $100 \%$ sensitivity and $88 \%$ specificity. By measuring the difference between supine and standing oxygen saturation, HPS could be detected with an oxygen saturation cutoff of $<96 \%[19,20]$.

\section{TREATMENT}

At present, LT remains the most effective therapy for HPS. A number of methods have been tested to halt the progression of HPS. Nitric oxide inhalation, low consumption of L-arginine using methylene blue, aspirin, antibiotic usage to reduce intestines bacterial translocation, somatostatin, indomethacin, garlic, and transjugular intrahepatic portosystemic shunt (TIPS) have not shown any particular benefit as long-term treatment of HPS [1, $2,21,22]$. According to theory, the use of TIPS could reduce portal hypertension and improve oxygenation. Wallace et al. had studied a series of successful cases of HPS managed by TIPS. They conclude that TIPS could be considered as a management option for HPS patients, in patients contraindicated for LT, in patients where dyspnea were progressive and incapacitating, and as a bridge to transplantation. However, the use of TIPS remained controversial due to the lack of large randomised controlled trials and unfavourable in most clinical settings [23].

The established 5-year survival rate was 23\% for HPS patients and $67 \%$ for patients without HPS. Another study showed that $33 \%-40 \%$ of HPS patients died within 2.5-4 years. Approximately $85 \%-100 \%$ of patients with HPS undergoing LT have an improvement in oxygenation within 1 year. Nevertheless, in some severe cases of hypoxemia, improvement may not be reached in only one year. These cases usually have a worse prognosis and a longer length of hospital stay [24-26].

One of the recent management options for life-threatening hypoxemia in HPS patients is extracorporeal membrane oxygenation (ECMO). This method has the capacity to support gas exchange and haemodynamics. Monsel et al. reported the use of EECMO in preparation of LT in patients with refractory hypoxemia caused by a combination of acute respiratory distress syndrome (ARDS) and HPS. The preliminary data showed that ECMO allowed the performing of successful LT by controlling gas exchange. Their research provided the basis to test ECMO on a large number of patients. Auzinger et al. also reported the successful case of using ECMO for severe refractory hypoxemia after LT in HPS patients. It could facilitate early ventilator weaning, thus prevented the need for the prolonged use of sedation and reduced complication associated with interventions. However, the effectiveness of ECMO must still be proven by future mulitcenter trials [28, 29].

For patients on the LT waiting list, it is extremely important to screen them for HPS besides their Model for End-Stage Liver Disease (MELD) scores as their survival rate was expected not to be as high as their non-HPS counterpart. However, data regarding the clinical features of HPS that might influence exception to the MELD scoring system were still limited. In the United States, Organ Procurement Transplant Network $(\mathrm{OPTN}) /$ United Network for Organ Sharing (UNOS) suggested that patients with $\mathrm{PaO}_{2}<60 \mathrm{mmHg}$ on room air in sitting position should receive an increase in their MELD score and they should get a 2 to 3 point increase every 3 months during their waiting period. It was indicated that patients who had LT this way exhibited a better survival rate and that post-LT mortality was not dependent on severity of hypoxemia at the time of HPS diagnosis. In the largest cohort study of HPS patients reported 
to date, Goldbert et al. provided the proof that LT is feasible in patients with HPS and resulted in a similar post-LT survival rate compared to non-HPS recipients $[30,31]$.

One of the major complications in LT is severe hypoxemia in the early postoperative period as patient in this population often resulted in death. However, the condition is poorly defined. Nayyar et al. reviewed 27 studies and defined severe hypoxemia as hypoxemia requiring $100 \%$ fraction of inhaled oxygen to maintain a saturation of $85 \%$. They also found that there was a liability in patients with very severe preoperative hypoxemia, defined as $\mathrm{PO}_{2} \leq 50 \mathrm{mmHg}$, for having an increased risk of developing the complication. This suggested the need for increased preoperative attention for severe hypoxemia among high-risk patients [32].

\section{CONCLUSION}

HPS is a serious complication of liver and/ orlung disease. At present, the main stay effective therapy to HPS is still LT. Therefore, an early diagnosis regarding HPS has to be done as soon as possible. Study to find a more effective diagnosis and therapeutic modality needs to be done more thoroughly. With accurate diagnosis, we could make a prioritized list of LT for HPS patients. In spite of its poor prognosis, we could improve quality of life and survival rate of patients.

Acknowledgement: There is no sponsor and possible conflicts of interest.

Conflict of Interest Disclosure: The authors declare that there are not conflicts of interest.

Sindromul hepatopulmonar este o complicație pulmonară a bolii hepatice caracterizată prin hipoxemie. Mecanismele implicate sunt modificări ale capacității de difuzie, defectele de ventilație-perfuzie şi şunturile directe arterio-venoase. Diagnosticul afecțiunii se bazează pe prezența bolii hepatice sau a hipertensiunii portale, creşterea gradientului de oxygen alveolo-arterial şi dilatările vasculare pulmonare. Transplantul renal rămâne singura terapie eficientă pentru această patologie. Deşi prognosticul acestei afecțiuni este rezervat, calitatea vieții şi supraviețuirea pacienților poate fi îmbunătățită.

Correspondence to: Zulkifli Amin, MD, PhD, Division of Respirology and Critical Care, Department of Internal Medicine, Faculty of Medicine, University of Indonesia, Salemba Raya Street No. 6, Jakarta, Indonesia, 10430, Phone: +62816819034 E-mail: pulmonologi89@yahoo.co.id

\section{REFERENCES}

1. TUMGOR G. Cirrhosis and hepatopulmonary syndrome. World J Gastroenterol. 2014; 20(10):2586-94.

2. RAEVENS S., GEERTS A., STEENKISTE CV., VERHELST X., VLIERBERGHE HV., COLLE I. Hepatopulmonary syndrome and portopulmonary hypertension: recent knowledge in pathogenesis and overview of clinical assessment. Liver Int. 2015:1478-3223.

3. FRITZ JS., FALLON MB., KAWUT SM. Pulmonary vascular complications of liver disease. Am J RespirCrit Care Med. 2013; 187:133-43.

4. FALLON MB., ZHAN GJ. The lung in liver disease: old problem, new concepts. Trans Am Clin Climatol Assoc. 2013; 124: 250-62.

5. SHAH R., MOUS AO., JOHN S. Hepatopulmonary syndrome: a rare diagnosis or missed entity. Q J Med. 2014; 107:565-66.

6. GRACE JA., ANGUS PW. Hepatopulmonary syndrome: update on recent advances in pathophysiology, investigation, and treatment. J Gastroenterol Hepatol. 2013; 28:213-9

7. KIM BJ., LEE SC., PARK SW., CHOI MS., KOH KC., PAIK SW., et al. Characteristics and prevalence of intrapulmonary shunt detected by contrast echocardiography with harmonic imaging in liver transplant candidates. Am J Cardiol. 2004; 94:525-8.

8. ZHANG J., FALLON MB. Hepatopulmonary syndrome: update on pathogenesis and clinical features. Nat Rev Gastroenterol Hepatol. 2012; 9(9):539-49.

9. FENG G., RONG H. The role of hemodynamic and vasoactive substances on hepatopulmonary syndrome. 2014; $18: 380-86$.

10. KOCH DG., BOGATKEVICH G., RAMSHESH V., LEMASTERS JJ., UFLACKER R., REUBEN A. Elevated levels of endothelin-1 in hepatic venous blood are associated with intrapulmonary vasodilatation in humans. Dig Dis Sci 2012; 57:516-23.

11. THENAPPAN T., GOEL A., MARSBOOM G., FANG YH., TOTH PT., ZHANG HJ., et al. A central role for CD68(+) macrophages in hepatopulmonary syndrome reversal by macrophage depletion. Am J Respir Crit Care Med. 2011; 183:1080-91. 
12. ROBERTS KE., KAWUTS M., KROWKA MJ., BROWN RS., TROTTER JF., SHAH V., et al. Genetic risk factors for hepatopulmonary syndrome in patients with advanced liver disease. Gastroenterology. 2010; 139:130-9.

13. MELO-SILVA CA., GAIOE., TREVIZOLI JE., SOUZA CS., GONCALVES AS., SOUSA GC., et al. Respiratory mechanics and lung tissue remodeling in a hepatopulmonary syndrome rat model. Respir Physiol Neurobiol. 2011; 179:326-33.

14. NACIF LS., ANDRAUS W., PINHEIRO RS., DUCATTI L., HADDAD LBP., D' ALBUQUERQUE LC. The hepatopulmonary syndrome. Arq Bras Cir Dig. 2014; 27(2):145-7.

15. MACHICAO VI., FALLON MB. Hepatopulmonary syndrome. Semin Respir Crit Care Med. 2012; 33(1):11-6.

16. SILVERIO AO., GUIMARAES DC., ELIAS LFQ., MILANEZ EO., NAVES S. Are the spider angiomas skin markers of hepatopulmonary syndrome? Arq Gastroenterol. 2013;50(3):175-178.

17. LV Y., FAN D. Hepatopulmonary syndrome. Dig Dis Sci. 2015 Jul; 60(7):1914-23.

18. KHABBAZA JE., KRASUSKI RA., TONELLI AR. Intrapulmonary shunt confirmed by intracardiac echocardiography in the diagnosis of hepatopulmonary syndrome. Hepatology. 2013 October; 58(4):1514-15.

19. KROWKA MJ. Hepatopulmonary syndrome: monitoring at your fingertip. Dig Dis Sci. 2011Jun; 56(6):1599-600.

20. SUCEVEANU AI., MAZILU L., TOMESCO D., CIUFU N., PAREPA IR., SUCEVEANU AP. Screening of hepatopulmonary syndrome (HPS) with CEUS and pulse-oximetry in liver cirrhosis patients eligible for liver transplant. Chirurgia. 2013; 108(5): 684-688.

21. SILVA HM., REIAS G., GUEDES M., CLETO E., VIZCAINO JR., GENNERY AR., et al. A case of hepatopulmonary syndrome solved by mycophenolate mofetil (an inhibitor of angiogenesis and nitric oxide production). J Hepatol. 2013; 58:630-33.

22. ESRAGHIAN A., KAMYAB AA., KEW-YOON S. Pharmacological treatment for hepatopulmonary syndrome. Biomed Res Int. 2013.

23. WALLACE MC., JAMES AL., MARSHALL M., KONTORINIS N.Resolution of severe hepatopulmonary syndrome following transjugular portosystemic shunt procedure. BMJ Case Reports. 2012.

24. ENACHE I., OSWALD-MAMMOSSER M., WOEHL-JAEGLE ML., HABERSETZER F., DI MARCO P., CHARLOUX A., et al. Cirrhotic cardiomyopathy and hepatopulmonary syndrome: prevalence and prognosis in a series of patients. Respir Med. 2013; 107:1030-36.

25. GUPTA S., CASTEL H., RAO RV., PICARD M., LILLY L., FAUGHNAN ME., et al. Improved survival after liver transplantation in patients with hepatopulmonary syndrome. Am J Transplant. 2010; 10:354-63.

26. PASCASIO JM., GRILO I., LOPEZ-PARDO FJ., ORTEGA-RUIZ., TIRADO JL., SOUSA JM. Prevalence and severity of hepatopulmonary syndrome and its influence on survival in cirrhotic patients evaluated for liver transplantation. Am J Tranpl. 2014; 14: 1391-99.

27. YUICHI C., EGAWA H., TSUBOI T., OGA T. HONDA T., YAMAMOTO K., et al. Immediate noninvasive ventilation may improve mortality in patients with hepatopulmonary syndrome after liver transplantation. Liver Transpl. 2011; 17:144-48.

28. MONSEL A., MAL H., BRISSON H., LUO R., EYRAUD D., VEZINET C., et al. Extracorporeal membrane oxygenation as a bridge to liver transplantation for acute respiratory distress syndrome-induced life threatening hypoxemia aggravated by hepatopulmonary syndrome. Crit Car. 2011; 15: R234.

29. AUZINGER G., WILlARS C., LOVERIDGE R., BEST T., VERCUEIL A., PRACHALIAS A., et al. Extracorporeal membrane oxygenation for refractory hypoxemia after liver transplantation in severe hepatopulmonary syndrome: a solution with pitfalls. Liver Transpl. 2014; 20:1141-1144.

30. GOLDBERG DS., KROK K., BATRA S., TROTTER JF., KAWUT SM., FALLON MB. Impact of the hepatopulmonary syndrome MELD exception policy on outcomes of patients after liver transplantation: an analysis of UNOS database. Gastroenterology. 2014 May; 146(5) 1256-65.

31. AGUILAR MP., GALLEGOS-OROZCO JF. Hepatopulmonary syndrome: is it time to redefine the MELD exception score for better organ allocation and outcomes? Ann Hepatol. 2014; 13(4):468-70.

32. NAYYAR D., MAN HSJ., GRANTON J., GUPTA S. Defining and characterizing severe hypoxemia after liver transplantation in hepatopulmonary syndrome. Liver Transpl. 2014; 20(2): 182-90

Received October 9, 2015 